\title{
The binding of peroxidase-labelled lectins to human endometrium in normal cyclical endometrium and endometrial adenocarcinoma
}

\author{
K P WEST, JANET L COPE \\ From the Department of Pathology, Clinical Sciences Building, Leicester Royal Infirmary, Leicester
}

SUMMARY The nature of endometrial glycoconjugates throughout the menstrual cycle was investigated using a panel of lectins directed against specific sugar groups. This approach was also applied to a series of endometrial adenocarcinomas the findings for which were compared with those of normal controls. A change in the expression of glycosubstances was found in relation to the phase of the menstrual cycle; that there was increasing sialylation of terminal galactose groups during the secretory phase. This change may be influenced by progesterone. One group of endometrial adenocarcinomas exhibited binding patterns similar to those seen in secretory endometrium and this may be related to progesterone receptor state. Expression of fucose containing glycosubstances was identified in half of the carcinomas but not in the normal control tissue, thus indicating that a change in fucosylation occurs with endometrial neoplasia. None of the lectin binding patterns, however, correlated with variables in the patients themselves or within the tumours.

Lectins are proteins and glycoproteins derived from a wide variety of biological sources. Their various properties depend on their ability to bind specifically to certain saccharide residues. They are thus able to react with the glycosylated components of cells and have been extensively used in the study of both normal and neoplastic tissues including breast ${ }^{1-4}$ and large intestine. $^{5-7}$ Studies of lectin binding in human endometrium have, however, been rather limited. ${ }^{8}$

Various metabolic changes occur in the endometrium during the normal menstrual cycle, and changes in the activities of enzymes such as nonspecific esterases, lactate dehydrogenase, and alkaline phosphatase have been recorded. ${ }^{910}$ Glycogen is synthesised at certain stages of the cycle and changes in glycoprotein production also occur. ${ }^{10}$ Standard techniques of carbohydrate histochemistry such as periodic acid Schiff (PAS) and alcian blue have been applied to human endometrium. "The use of lectins, however, permits more specific identification of changes in tissue carbohydrates which occur during the menstrual cycle.

The glycosylated components of cells and particularly of cell membranes have been implicated in several cellular reactions such as cell-cell interaction,

Accepted for publication I September 1988 cell-substrate interaction, and hormone binding. ${ }^{12-14}$ Changes in such properties could be important in the development of neoplasia and several studies have been performed comparing the glycosubstances of neoplastic cells with their normal counterparts. ${ }^{1516}$ Lectins-for example, peanut and wheat germ agglutinins-have been previously used to detect changes in the carbohydrate composition of malignant cells both in tissue sections ${ }^{16}$ and in cell suspensions. ${ }^{1718}$ Only one previous study of lectin binding to human endometrial carcinoma, however, has been undertaken. ${ }^{8}$

The purpose of this study was to determine the pattern of lectin binding in endometrium during different phases of the menstrual cycle, to assess the reactivity of endometrial carcinomas, and to compare these to those of non-malignant tissues. The seven lectins used have a range of specificities encompassing galactose and $\mathrm{N}$-acetyl-D-galactosamine, $\mathrm{N}$-acetyl-Dglucosamine, sialic acid, fucose and mannose.

\section{Material and methods}

Fifty cases each of proliferative endometrium, secretory endometrium, and endometrial adenocarcinoma were retrieved from the histopathology files of this hospital. All specimens had been fixed in $10 \%$ 
Table 1 Lectins selected for use in this study

\begin{tabular}{|c|c|c|c|}
\hline Source & Acronym & $\begin{array}{l}\text { Sugar-sugar } \\
\text { specificity }\end{array}$ & Inhibitor \\
\hline $\begin{array}{l}\text { Triticum vulgare } \\
\text { (Wheat germ) }\end{array}$ & WGA & $\begin{array}{l}\text { N-acetyl-D- } \\
\text { glucosaminyl } \\
\text { residues }^{22}{ }_{23} \text { sialyl } \\
\text { residues }^{24}\end{array}$ & $\begin{array}{l}\mathrm{N} \text {-acetyl-D- } \\
\text { glucosamine }\end{array}$ \\
\hline $\begin{array}{l}\text { Arachis hypogaea } \\
\text { (Peanut) }\end{array}$ & PNA & $\begin{array}{l}\text { Galactosyl- } \beta \\
\text { 1-3-N-acetyl- } \\
\text { D-galacto-aminyl } \\
\text { residues }^{25} 26\end{array}$ & D-galactose \\
\hline $\begin{array}{l}\text { Dolichos biflorus } \\
\text { [Horse gram) }\end{array}$ & DBA & $\begin{array}{l}\text { N-acetyl-D- } \\
\text { galactosaminyl } \\
\text { residues }^{27}\end{array}$ & $\begin{array}{l}\mathrm{N} \text {-acetyl-D- } \\
\text { galactosamine }\end{array}$ \\
\hline $\begin{array}{r}\text { Maclura pomifera } \\
\text { (Osage orange) }\end{array}$ & MPA & $\begin{array}{l}\mathrm{N} \text {-acetyl-D- } \\
\text { glactosaminyl } \\
\text { and } \alpha \text {-D-galactosyl } \\
\text { residues }^{2830}\end{array}$ & $\begin{array}{l}\text { N-acetyl-D- } \\
\text { galactosamine } \\
\text { D-galactose }\end{array}$ \\
\hline $\begin{array}{l}\text { Bandeiraea } \\
\quad \text { simplicifolia }\end{array}$ & BSA-1 & $\begin{array}{l}\alpha \text {-D-galactosyl } \\
\text { residues }^{31}\end{array}$ & D-galactose \\
\hline $\begin{array}{l}\text { Ulex europaeus } \\
\text { (Gorse) }\end{array}$ & UEA-1 & $\begin{array}{l}\text { Fucosyl } \\
\text { residues }^{3233}\end{array}$ & L-fucose \\
\hline $\begin{array}{l}\text { Lens culinaris } \\
\quad \text { (Lentil) }\end{array}$ & LCA & $\begin{array}{l}\alpha-D-m a n n o s y l \text { and } \\
\alpha \text {-D-glycosyl } \\
\text { residues }^{34}\end{array}$ & $\begin{array}{l}\alpha \text {-methyl- } \\
\text { manno-pyranoside }\end{array}$ \\
\hline
\end{tabular}

unbuffered formol-saline and routinely processed to paraffin wax. In the cases of carcinoma the ages of the patients and their $\mathrm{ABO}$ blood group state were also recorded. Details of $\mathrm{ABO}$ blood groups were not

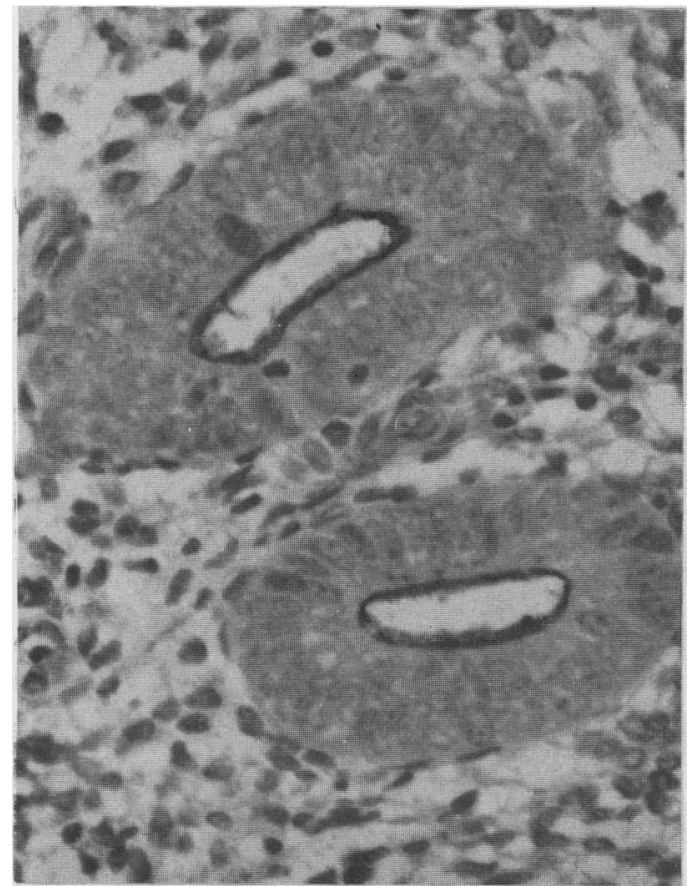

Fig 1 Proliferative endometrium stained with HRP-PNA. There is strong staining at luminal surfaces of endometrial glands. available for the proliferative and secretory endometrium groups.

Sections stained with haematoxylin and eosin were examined to confirm the stage of the menstrual cycle using established criteria ${ }^{19}$ and the endometrial adenocarcinomas were graded into well, moderately, and poorly differentiated.

Horseradish peroxidase (HRP) conjugated lectins were obtained from Sigma Ltd (Poole, Dorset, England) and E-Y Laboratories (San Mateo, California, USA). After initial evaluation of concentrations ranging from $5-50 \mu \mathrm{g} / \mathrm{ml}$ a standard optimum concentration of $10 \mu \mathrm{g} / \mathrm{ml}$ was used for all lectins.

The staining procedure was as follows:

1 Deparaffinise $4 \mu \mathrm{m}$ sections.

2 Block endogenous peroxidase activity for $30 \mathrm{~min}$ utes in $0.5 \% \mathrm{H}_{2} \mathrm{O}_{2}$ in absolute methanol.

3 Wash in phosphate buffered saline (PBS).

4 Incubate with HRP lectin conjugate for 60 minutes at room temperature.

5 Wash in PBS.

6 Develop reaction product by incubation in $0.015 \%$ $\mathrm{H}_{2} \mathrm{O}_{2}$ and $0.05 \%$ diaminobenzidine tetrahydrochloride in PBS for five minutes.

7 Counterstain with haematoxylin.

The binding of all lectins was assessed both with and without pretreatment with $0 \cdot 1 \%$ trypsin (Difco) with $0.1 \%$ calcium chloride in distilled water for 30 minutes at $37^{\circ} \mathrm{C}$ as enzyme digestion has been found to enhance the binding of lectins to paraffin wax sections in some instances. ${ }^{20}$ Similarly, the effect of neuraminidase on the binding of all the lectins was assessed by treatment of sections overnight with Vibrio cholerae neuraminidase (Koch-Light), $250 \mu \mathrm{g} / \mathrm{ml}$ in $0.1 \mathrm{M}$ sodium acetate buffer, pH $5 \cdot 5$, containing $0.005 \mathrm{M}$ calcium chloride. ${ }^{21}$ Controls were performed by omission of the HRP lectin conjugate and by incubation of the conjugates with appropriate and inappropriate inhibitory sugars at a concentration of $0.2 \mathrm{M}$.

The lectins used, together with their simple sugar specificities and the inhibitory sugars used as controls are shown in table 1 .

\section{Results}

Previous digestion of tissue sections with trypsin, while slightly enhancing the intensity of staining in a small number of cases, had no effect on the distribution of reactivity with any of the lectins used. Staining with all the lectins except Lens culinaris (LCA) was inhibited by incubation with the appropriate inhibitory sugars as shown in table 1. As LCA did not stain any of the cases studied the effect of its inhibitor could not be assessed. The binding of Triticum vulgare (WGA), Ulex europaeus (UEA), Dolichos biflorus (DBA) and LCA was unaffected by pretreatment with neuraminidase. 


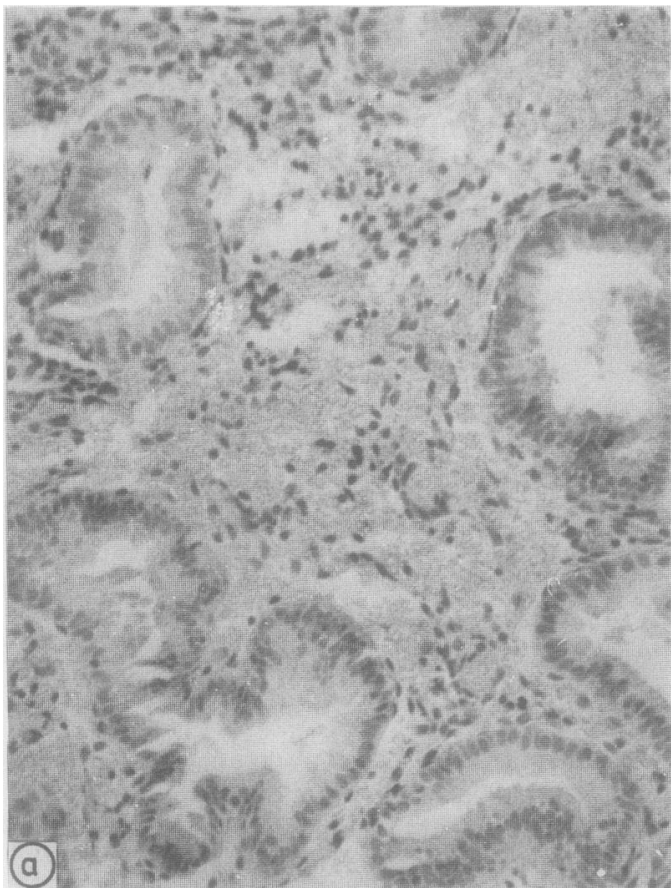

Fig 2a Secretory endometrium stained with HRP-PNA without neuraminidase incubation. No positive staining is evident.

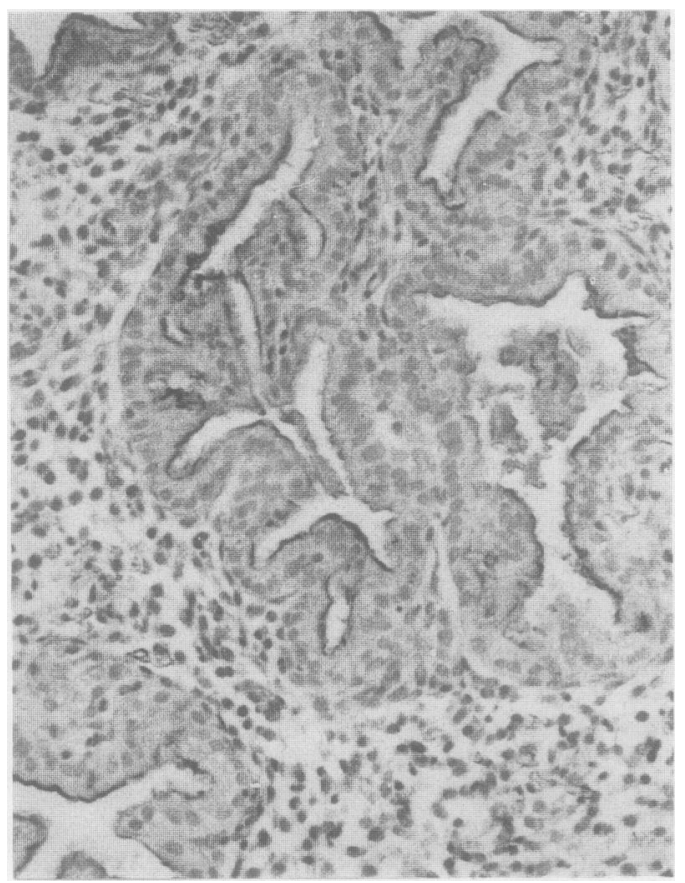

Fig 3 Secretory endometrium stained with HRP-BSA following incubation with neuraminidase. Luminal surface staining of endometrial glands is evident.

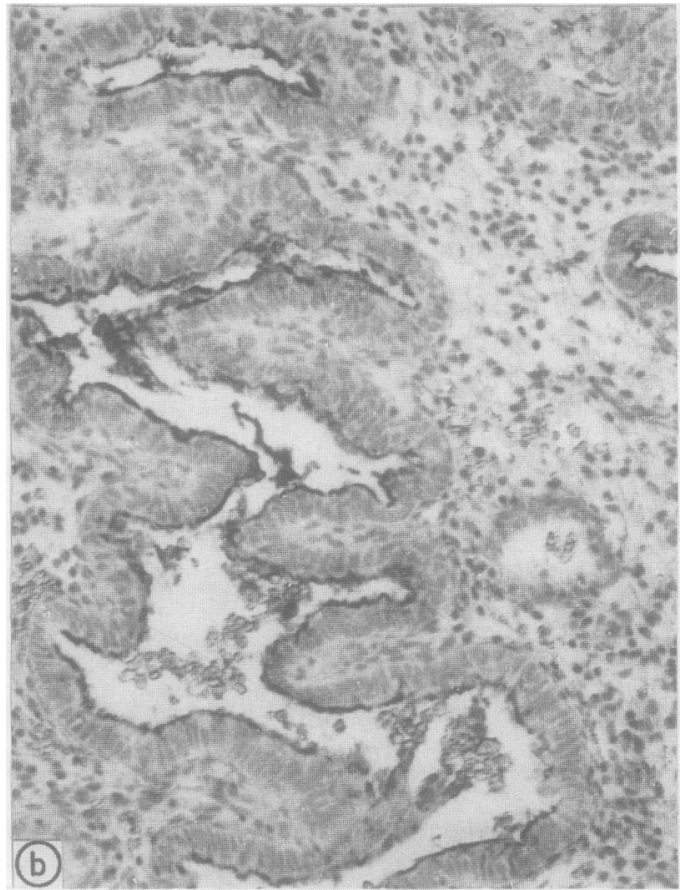

Fig $2 \mathrm{~b}$ Secretory endometrium stained with HRP-PNA following incubation with neuraminidase. There is strong luminal surface staining of endometrial glands.

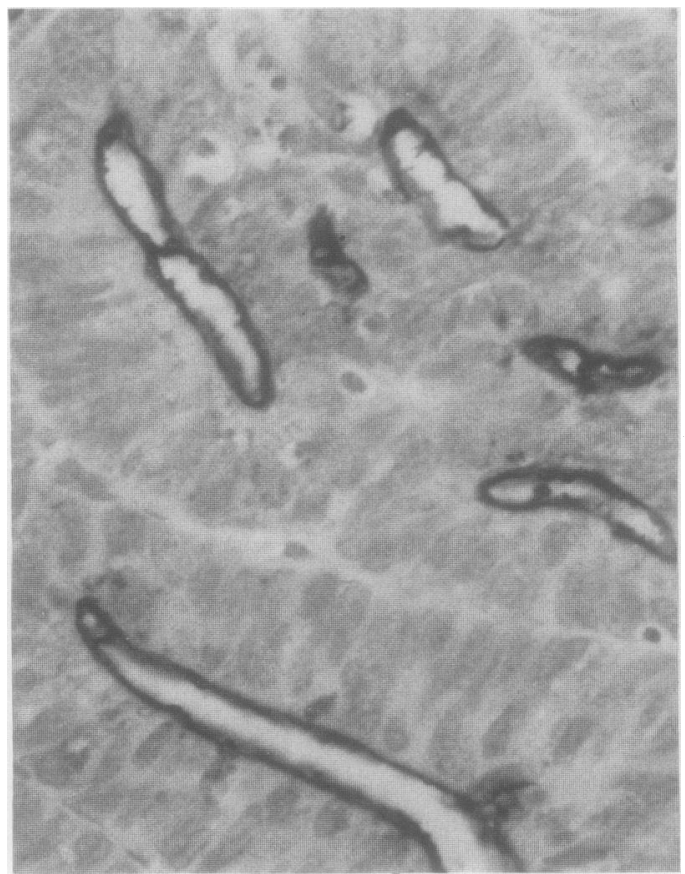

Fig 4 Endometrial adenocarcinoma stained with HRP-PNA without neuraminidrse. There is strong staining of surfaces of neoplastic glands. 
Table 2 Summary of results of lectin binding to cyclical endometrium

\begin{tabular}{|c|c|c|c|c|}
\hline Lectin & Proliferative $(n=50)$ & Early secretory $(n=22)$ & Mid-secretory $(n=18)$ & Late secretory $(n=10)$ \\
\hline After neuraminidase & $\begin{array}{l}50 / 50 \text { Luminal surface } \\
\text { and cytoplasmic } \\
\text { staining in all glands } \\
50 / 50 \text { No change }\end{array}$ & $\begin{array}{l}22 / 22 \text { Luminal surface } \\
\text { and cytoplasmic } \\
\text { staining in all glands } \\
22 / 22 \text { No change }\end{array}$ & $\begin{array}{l}\text { 18/18 Luminal surface } \\
\text { and cytoplasmic } \\
\text { staining in all glands } \\
18 / 18 \text { No change }\end{array}$ & $\begin{array}{l}10 / 10 \text { Luminal surface } \\
\text { and cytoplasmic } \\
\text { staining in all cases } \\
10 / 10 \text { No change }\end{array}$ \\
\hline PNA & $\begin{array}{l}\text { 50/50 Luminal surface } \\
\text { staining of all glands } \\
\text { (fig l) }\end{array}$ & $\begin{array}{l}\text { 22/22 Luminal surface } \\
\text { staining of all glands }\end{array}$ & $\begin{array}{l}\text { 18/18 Patchy luminal } \\
\text { surface staining }\end{array}$ & $10 / 10$ Negative \\
\hline After neuraminidase & $50 / 50$ No change & $22 / 22$ No change & $\begin{array}{l}\text { 18/18 Luminal surface } \\
\text { staining of all glands }\end{array}$ & $\begin{array}{l}\text { 10/10 Luminal surface } \\
\text { staining of all glands } \\
\text { (fig 2) }\end{array}$ \\
\hline After neuraminidase & $\begin{array}{l}\text { 3/50 Negative } \\
47 / 50 \text { Diffuse epithelial } \\
\text { cytoplasmic staining }\end{array}$ & $\begin{array}{l}\text { 12/22 Negative } \\
\text { 10/22 Supranuclear and } \\
\text { apical cytoplasmic } \\
\text { staining } \\
\text { Variable luminal } \\
\text { surface staining } \\
\text { 22/22 No change }\end{array}$ & $\begin{array}{l}\text { 10/18 Negative } \\
\text { 8/18 Supranuclear and } \\
\text { apical cytoplasmic } \\
\text { staining } \\
\text { Variable luminal } \\
\text { surface staining } \\
\text { 18/18 No change }\end{array}$ & $\begin{array}{l}5 / 10 \text { Negative } \\
5 / 10 \text { Supranuclear and } \\
\text { apical cytoplasmic } \\
\text { staining } \\
\text { Variable luminal } \\
\text { surface staining } \\
10 / 10 \text { No change }\end{array}$ \\
\hline MPA & $\begin{array}{l}\text { 50/50 Supranuclear } \\
\text { cytoplasmic staining } \\
\text { Luminal surfaces } \\
\text { negative }\end{array}$ & $\begin{array}{l}\text { 22/22 Supranuclear } \\
\text { cytoplasmic staining } \\
\text { Luminal surfaces } \\
\text { negative }\end{array}$ & $\begin{array}{l}\text { 18/18 Supranuclear } \\
\text { cytoplasmic staining } \\
\text { Luminal surfaces } \\
\text { negative }\end{array}$ & $\begin{array}{l}\text { 10/10 Supranuclear } \\
\text { cytoplasmic staining } \\
\text { Luminal surfaces } \\
\text { negative }\end{array}$ \\
\hline After neuraminidase & $\begin{array}{l}50 / 50 \text { Luminal surface } \\
\text { staining }\end{array}$ & $\begin{array}{l}\text { 22/22 Luminal surface } \\
\text { staining }\end{array}$ & $\begin{array}{l}\text { 18/18 Luminal surface } \\
\text { staining }\end{array}$ & $\begin{array}{l}\text { 10/10 Luminal surface } \\
\text { staining }\end{array}$ \\
\hline $\begin{array}{l}\text { BSA-1 } \\
\text { After neuraminidase }\end{array}$ & $\begin{array}{l}50 / 50 \text { Negative } \\
50 / 50 \text { Luminal surface } \\
\text { staining }\end{array}$ & $\begin{array}{l}\text { 22/22 Negative } \\
\text { 22/22 Luminal surface } \\
\text { staining }\end{array}$ & $\begin{array}{l}\text { 18/18 Negative } \\
\text { 18/18 Luminal surface } \\
\text { staining }\end{array}$ & $\begin{array}{l}\text { 10/10 Negative } \\
\text { 10/10 Luminal surface } \\
\text { staining (fig 3) }\end{array}$ \\
\hline UEA-1 & $\begin{array}{l}\text { 45/50 Negative } \\
5 / 50 \text { focal luminal } \\
\text { surface staining }\end{array}$ & 22/22 Negative & $18 / 18$ Negative & $10 / 10$ Negative \\
\hline After neuraminidase & $50 / 50$ No change & 22/22 No change & $18 / 18$ No change & $10 / 10$ No change \\
\hline $\begin{array}{l}\text { LCA } \\
\text { After neuraminidase }\end{array}$ & $\begin{array}{l}50 / 50 \text { Negative } \\
50 / 50 \text { No change }\end{array}$ & $\begin{array}{l}\text { 22/22 Negative } \\
22 / 22 \text { No change }\end{array}$ & $\begin{array}{l}\text { 18/18 Negative } \\
18 / 18 \text { No change }\end{array}$ & $\begin{array}{l}\text { 10/10 Negative } \\
10 / 10 \text { No change }\end{array}$ \\
\hline
\end{tabular}

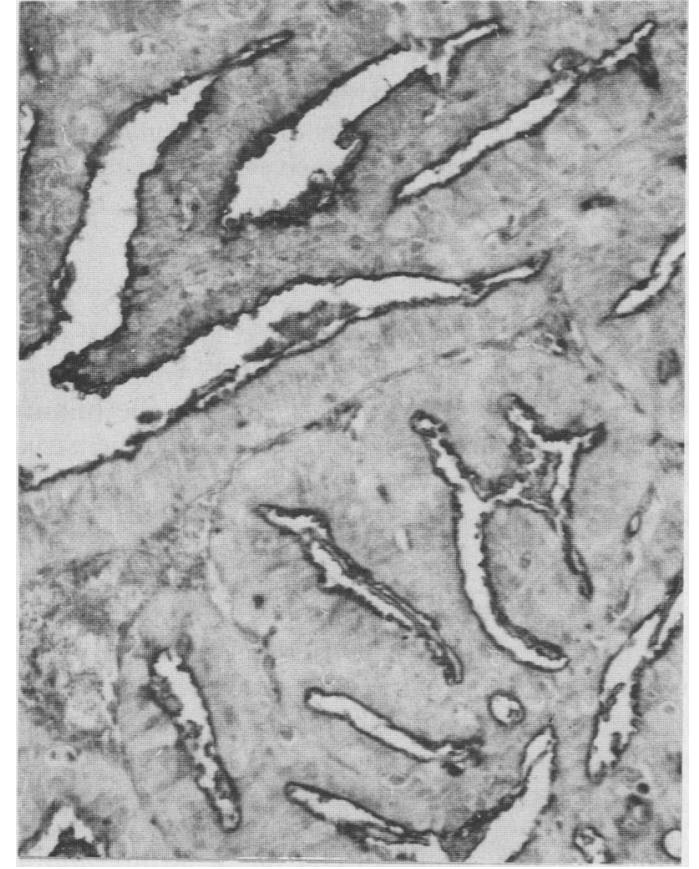

Fig 5 Endometrial adenocarcinomas stained with $H R P$ $U E A$. Glandular surfaces and secretions show staining.

\section{CYCLICAL ENDOMETRIUM}

The cases of secretory endometrium were classified as early secretory $(n=22)$, mid-secretory $(n=18)$, and late secretory $(n=10)$. Consistent patterns of binding were observed with WGA, PNA, Maclura pomifera (MPA), Bandideiraea simplicifolia (BSA-1) and UEA1 with differences being noted between proliferative and secretory endometrium for PNA and to a lesser extent DBA. The results are summarised in table 2.

\section{CARCINOMAS}

The endometrial adenocarcinomas were categorised as well differentiated $(n=34)$, moderately differentiated $(n=10)$, and poorly differentiated $(n=6)$. No correlation between the degree of differentiation and lectin binding, however, was observed. Furthermore, there was no association between lectin binding and age or ABO blood group. The results of the lectin binding studies are summarised in table 3 .

PNA staining of tumour cell cytoplasm and luminal surfaces was observed in all carcinomas. Three groups of tumours could be identified. Ten cases showed scanty staining with less than $10 \%$ of the tumour reacting; 31 cases showed moderate staining with about $50 \%$ of the tumour being reactive; and nine cases showed abundant staining with more than $90 \%$ of the tumour reacting. Prior treatment with 
Table 3 Summary of results of lectin binding to endometrial adenocarcinomas

\begin{tabular}{|c|c|c|c|}
\hline Lectin & Well-differentiated $(n=34)$ & Moderately differentiated $(n=10)$ & Poorly differentiated $(n=6)$ \\
\hline After neuraminidase & $\begin{array}{l}\text { 34/34 Widespread luminal } \\
\text { surface staining } \\
\text { Variable cytoplasmic staining } \\
\text { 34/34 No change }\end{array}$ & $\begin{array}{l}\text { 10/10 Widespread luminal } \\
\text { surface staining } \\
\text { Variable cytoplasmic staining } \\
\text { 10/10 No change }\end{array}$ & $\begin{array}{l}\text { 6/6 Widespread luminal surface } \\
\text { staining } \\
\text { Variable cytoplasmic staining } \\
\text { 6/6 No change }\end{array}$ \\
\hline PNA & $\begin{array}{l}\text { 6/34 Scanty staining }(<10 \%) \\
\text { (fig 4) } \\
\text { 22/34 Moderate staining } \\
\text { (c50\%) } \\
6 / 34 \text { Abundant staining } \\
(>90 \%)\end{array}$ & $\begin{array}{l}\text { 2/10 Scanty staining } \\
6 / 10 \text { Moderate staining } \\
\text { 2/10 Abundant staining }\end{array}$ & $\begin{array}{l}\text { 2/6 Scanty staining } \\
\text { 2/6 Moderate staining } \\
\text { 2/6 Abundant staining }\end{array}$ \\
\hline After neuraminidase & 34/34 Abundant staining & 10/10 Abundant staining & 6/6 Abundant staining \\
\hline DBA & $\begin{array}{l}\text { 18/34 Negative } \\
\text { 10/34 Cytoplasmic staining } \\
\text { alone }\end{array}$ & $\begin{array}{l}\text { 4/10 Negative } \\
\text { 4/10 Cytoplasmic staining only }\end{array}$ & $\begin{array}{l}\text { 3/6 Negative } \\
\text { 2/6 Cytoplasmic staining alone }\end{array}$ \\
\hline After neuraminidase & $\begin{array}{l}\text { 6/34 Cytoplasmic and luminal } \\
\text { surface staining } \\
34 / 34 \text { No change }\end{array}$ & $\begin{array}{l}\text { 2/10 Cytoplasmic and luminal } \\
\text { surface staining } \\
\text { 10/10 No change }\end{array}$ & $\begin{array}{l}\text { 1/6 Cytoplasmic and luminal } \\
\text { surface staining } \\
6 / 6 \text { No change }\end{array}$ \\
\hline MPA & $\begin{array}{l}\text { 10/34 Cytoplasmic staining } \\
\text { 9/34 Luminal surface staining } \\
\text { 15/34 Cytoplasmic and luminal } \\
\text { surface staining }\end{array}$ & $\begin{array}{l}\text { 1/10 Negative } \\
3 / 10 \text { Cytoplasmic staining } \\
4 / 10 \text { Luminal suurface staining } \\
\text { 2/10 Cytoplasmic and luminal } \\
\text { surface staining }\end{array}$ & $\begin{array}{l}\text { 2/6 Cytoplasmic staining } \\
1 / 6 \text { Luminal surface staining } \\
\text { 3/6 Cytoplasmic and luminal } \\
\text { surface staining }\end{array}$ \\
\hline After neuraminidase & $\begin{array}{l}34 / 34 \text { Luminal surface staining } \\
\text { Cytoplasmic staining } \\
\text { unchanged }\end{array}$ & $\begin{array}{l}\text { 9/10 Luminal surface staining } \\
\text { Cytoplasmic staining } \\
\text { unchanged }\end{array}$ & $\begin{array}{l}\text { 6/6 Luminal surface staining } \\
\text { Cytoplasmic staining } \\
\text { unchanged }\end{array}$ \\
\hline BSA-1 & $\begin{array}{l}\text { 27/34 Negative } \\
\text { 7/34 Luminal surface staining }\end{array}$ & $\begin{array}{l}\text { 7/10 Negative } \\
3 / 10 \text { Luminal surface staining }\end{array}$ & $\begin{array}{l}\text { 3/6 Negative } \\
3 / 6 \text { Luminal surface staining }\end{array}$ \\
\hline After neuraminidase & $\begin{array}{l}\text { Negative cases unchanged } \\
\text { Increased surface staining in } \\
\text { positive cases }\end{array}$ & $\begin{array}{l}\text { Negative cases unchanged } \\
\text { Increased surface staining in } \\
\text { positive cases }\end{array}$ & $\begin{array}{l}\text { Negative cases unchanged } \\
\text { Increased surface staining in } \\
\text { positive cases }\end{array}$ \\
\hline UEA-1 & $\begin{array}{l}\text { 15/34 Negative } \\
\text { 19/34 Luminal surface staining } \\
\text { (fig 5) }\end{array}$ & $\begin{array}{l}\text { 4/10 Negative } \\
6 / 10 \text { Luminal surface staining }\end{array}$ & $\begin{array}{l}\text { 3/6 Negative } \\
3 / 6 \text { Luminal surface staining }\end{array}$ \\
\hline After neuraminidase & $34 / 34$ No change & $10 / 10$ No change & $6 / 6$ No change \\
\hline $\begin{array}{l}\text { LCA } \\
\text { After neuraminidase }\end{array}$ & $\begin{array}{l}34 / 34 \text { Negative } \\
34 / 34 \text { No change }\end{array}$ & $\begin{array}{l}10 / 10 \text { Negative } \\
10 / 10 \text { No change }\end{array}$ & $\begin{array}{l}\text { 6/6 Negative } \\
6 / 6 \text { No change }\end{array}$ \\
\hline
\end{tabular}

neuraminidase resulted in staining throughout all tumours.

\section{Discussion}

By using a range of lectins of different and related specificities, variations were detected between different phases of the menstrual cycle and between malignant and non-malignant endometrium. Although consistent patterns of binding have been noted for proliferative and secretory endometrium with most of the lectins, an interesting change in the sialylation of certain terminal galactosyl groups between the two phases was observed. Changes in sialylation and fucosylation were also shown in carcinomas.

Interpretation of the results of lectin binding studies requires great caution. Firstly, it should be emphasised that the results of this study apply only to endometrial tissue fixed in formalin and processed to paraffin wax; the use of other means of fixation may produce different results. The effects of various fixatives on lectin binding have been studied in breast, ${ }^{1}$ skin, and oral mucosa..$^{35}$ Furthermore, the binding of lectins is not as straightforward as simple inhibition experiments suggest, a point which must not be overlooked in considering the meaning of the results of lectin histochemistry. The use of specific glycosidases offers an alternative, but expensive means of control in lectin binding studies.

\section{CYCLICAL ENDOMETRIUM}

The results allow certain observations to be made about the nature of endometrial glycosubstances during the normal menstrual cycle. WGA binding sites were identified in the cytoplasm and at the luminal surfaces of epithelial cells throughout the menstrual cycle. WGA identifies $\mathrm{N}$-acetyl-D-glucosamine, ${ }^{22} 23$ especially in dimeric or trimeric form but will also bind to sialic (N-acetylneuraminic) acid. ${ }^{24}$ As neuraminidase preferentially cleaves terminal sialic acid residues $^{21}$ and it did not affect WGA binding, the lectin may be detecting N-acetyl-D-glucosamine in the endometrium. This cannot be stated with certainty, however, as we have no definitive proof that sialic acid is removed.

Despite apparent similarities lectins with affinity for D-galactosyl and N-acetyl-D-galactosaminyl residues produce varying results. PNA has a strong affinity for galactosyl- $\beta-(1-3)-N$-acetyl-D-galactosaminyl residues. ${ }^{2526}$ The staining of the luminal surfaces of 
proliferative glands suggests that this disaccharide is present. The loss of reactivity in the secretory phase and its restoration by neuraminidase treatment indicates that sialylation of the PNA binding sites has occurred. An increase in sialomucins in late secretory endometrium has previously been shown histochemically. ${ }^{36}$ This could be the result of increased sialyl transferase activity, and the timing of this change suggests a possible role for progesterone in its mediation. Serum progesterone activities rise during the secretory phase and there is an increase in endometrial progesterone receptors at this time. ${ }^{37}$

The binding of DBA also showed cyclical variations, although these were less pronounced than those seen with PNA. Terminal N-acetyl-D-galactosamine ${ }^{27}$ was detected at the luminal surface only in secretory endometrium. The distribution of this residue may, therefore, be controlled by a glycosyltransferase under hormonal influence.

MPA and BSA-1 showed consistent binding patterns throughout the menstrual cycle. MPA has affinity for $\alpha$-D-galactose and $\mathrm{N}$-acetyl-D-galactosamine ${ }^{2829}$ but will also bind to galactose- $\beta-(1-3)-\mathrm{N}$ acetyl-D-galactosamine as does PNA..$^{30}$ MPA binding sites were demonstrable in the endometrial epithelial cytoplasm and sialylated binding sites were present at the luminal surfaces. The cytoplasmic binding sites may represent nascent glycoproteins which then undergo sialylation before being transported to the luminal surface.

BSA-1 detected $\alpha$-D-galactosyl residues ${ }^{31}$ at the luminal surface of endometrial glands only after treatment with neuraminidase. Thus staining of endometrium with PNA and BSA-1 after such treatment identifies two oligosaccharides. One of these has a subterminal $\alpha$-D-galactose residue as detected by BSA-1: this is present throughout the cycle and could also be detected by MPA. The other has a subterminal galactose- $\beta$-(1-3)-N-acetyl-D-galactosamine detectable by PNA and is present in its complete form only in the secretory phase of the cycle.

With few exceptions, UEA-1 did not stain cyclical endometrium. This does not necessarily imply an absence of terminal L-fucose residues, however. UEA1 has a predilection for the blood group $\mathrm{H}(\mathrm{O})$ oligosaccharide-fucose-(1-2)- $\beta$-D-galactosyl-(1-4)-Nacetyl D-glucosamine-(1-6)-P. ${ }^{33} \mathrm{~L}$-fucose, therefore, may be present in human endometrium in a form undetectable by UEA-1. Details of blood groups were not available for the cyclical endometrium group. The results of Kluskens et al for staining of proliferative endometrium with UEA-1 are similar to those of the present study. ${ }^{8}$

CARCINOMAS

WGA binding sites occurred ubiquitously in endometrial adenocarcinoma as they did in cyclical endometrium.

Staining was unaffected by neuraminidase, thus indicating the widespread presence of $\mathrm{N}$-acetyl-Dglucosamine at the surface of neoplastic lumina and to a lesser extent in tumour cell cytoplasm.

After treatment with neuraminidase all carcinomas exhibited abundant staining with PNA, regardless of the extent of reactivity without enzymatic manipulation. Those tumours showing scanty staining without neuraminidase digestion may be likened to secretory endometrium, and possibly the differential sialylation of PNA binding sites may depend on hormones. Progesterone receptors have been detected in some endometrial adenocarcinomas. ${ }^{38}{ }^{39}$ The presence of such receptors could determine the extent of sialylation of PNA binding sites and might predict the response to progesterone treatment. As in normal endometrium the synthesis of the progesterone receptors may be influenced by oestrogen ${ }^{37}$ which has also been implicated in the pathogenesis of endometrial carcinoma. Another possible explanation of the variable sialylation of PNA binding sites is that some of the patients may have been receiving therapeutic progestogens. Clearly, further study of the association between PNA binding, steroid hormone concentrations, and tumour receptor state would be of value. Similar studies in breast carcinoma have found an association between PNA binding and oestrogen receptor content. ${ }^{40}$

Half of the cases of carcinoma showed DBA reactivity. The staining was heterogeneous and was not related to $\mathrm{ABO}$ blood group. In nine cases variable staining of glandular luminal surfaces and secretions was noted similar to the staining pattern observed in some cases of secretory endometrium. These findings, like those seen with PNA, may be the result of differences in hormonal environment or receptor state of the tumours.

Staining with MPA and BSA-1 showed differences in the sialylation of their binding sites in carcinomas compared with those of cyclical endometrium. Thirty four carcinomas showed luminal surface staining with MPA, without prior treatment with neuraminidase and similar findings were observed with BSA-1 in 13 cases. These results may be due to incomplete glycoprotein synthesis in some endometrial adenocarcinomas.

Variations in the fucosylation of carcinomas are detectable by UEA-1. Reactivity is not related to ABO blood group state so that staining of endometrial carcinomas by UEA-1 does not simply reflect the expression of the patients' own blood group antigens on their tumours. Kluskens et al showed very weak or no staining of proliferative endometrium by UEA-1 ${ }^{8}$ in keeping with the present results. In that investi- 
gation UEA-1 also failed to stain endometrial carcinomas. Such a finding is not wholly inconsistent with our results as only 15 cases of carcinoma were examined.

Lack of staining of cyclical endometrium and endometrial carcinomas by LCA indicates the absence of detectable bi-antennate and tri-antennate $\mathrm{N}$-linked glycans containing mannosyl residues. More than one commercial batch of the lectin was used, and other tissues comprising part of a different project were reactive. It therefore seems that the lack of staining by LCA in endometrial tissues was due to a lack of binding sites and not to any technical problems.

The results of this study show that HRP conjugated lectins can be used to show the presence of glycosylated components of both normal and neoplastic human endometrium in formalin fixed, paraffin wax processed tissues. Changes in these components can be detected at certain stages of the menstrual cycle and in neoplasia. Comparisons of binding patterns in normal proliferative and secretory endometrium with endometrial carcinomas, however, should be made with care as, by definition, the former come from premenopausal women and many of the latter are from postmenopausal women.

One avenue not explored in this study is the possible clinical importance of the extent and distribution of lectin staining in endometrial carcinomas in relation to tumour behaviour and prognosis. This could form the basis for a further study, as could a detailed study of lectin binding in atypical endometrial hyperplasia.

We thank Dr Rosemary Walker for helpful criticism in the preparation of the manuscript and Mrs Beverley Richardson, Mrs Wendy Pitts, and Mrs Margaret Hornby for their secretarial support.

\section{References}

1 Walker RA. The binding of peroxidase labelled lectins to human breast epithelium. I-Normal, hyperplastic and lactating breast. J Pathol 1984;142:279-91.

2 Walker RA. The binding of peroxidase labelled lectins to human breast epithelium. II-The reactivity of breast carcinomas to Wheat germ agglutinin. $J$ Pathol 1984;144:101-8.

3 Walker RA. The binding of peroxidase labelled lectins to human breast epithelium. III-Altered fucose binding patterns of breast carcinomas and their significance. $J$ Pathol 1984;144:109-18.

4 Walker RA. The binding of peroxidase labelled lectins to human breast epithelium. IV-The reaction of breast carcinomas to peanut, Soybean and Dolichos biflorus agglutinins. J Pathol 1985;145:269-77.

5 Boland CR, Montgomery CK, Kim YS. Alterations in human colonic mucin occurring with cellular differentiation and malignant transformation. Proc Natl Acad Sci USA 1982;79:2051-5.

6 Yonezawa S, Nakamura T, Tanaka S, Sato E. Glycoconjugate with Ulex europaeus-1-binding sites in normal mucosa, adenoma and carcinoma of the human large bowel. JNCI 1982;69: 777-85.

7 Bresalier RA, Boland CR, Kim YS. Characteristics of colorectal
7 Bresalier RA, Boland CR, Kim YS. Characteristics of colorectal carcinoma cells with high metastatic potential. Gastroenterology 1984;82:259-66.

8 Kluskens LF, Kluskens $\mathrm{JL}$, Bibbo $\mathrm{M}$. Lectin binding in endometrial adenocarcinoma. Am J Clin Pathol 1984;82: 259-66.

9 Spellman CM, Fottrell PF, Baynes S, O'Dwyer EM, Clinch JD. A study of some enzymes and isoenzymes of carbohydrate metabolism in human endometrium during the normal menstrual cycle. Clin Chim Acta 1973;48:259-68.

10 McKay DG, Hertig AT, Bardawil WA, Velardo JT. Histochemical observations on the endometrium. I-Normal endometrium. Obstet Gynecol 1956;8:22-39.

11 Nirmala V, Thomas JA. Endometrial mucin histochemistry in different phases of the normal menstrual cycle. Indian J Med Res 1982;76:229-34.

12 Hughes RC. Membrane glycoproteins. London: Butterworths, 1976.

13 Nicholson GL. Transmembrane control of the receptors on normal and malignant cells. Biochim Biophys Acta 1976;458: $1-57$.

14 Critchley DR. Glycolipids as membrane receptors important in growth regulation. In: Hynes RO, ed. Surfaces of normal and malignant cells. New York: John Wiley, 1979:63-101.

15 Warren L, Buck CA, Tuszynski GP. Glycopeptide changes and malignant transformation. A possible role for carbohydrates in malignant transformation. Biochim Biophys Acta 1978;516: 97-127.

16 Hakomori S. Structure and organization of cell surface glycolipid dependency on cell growth and malignant transformation. Biochim Biophys Acta 1975;419:55-89.

17 Aub JC, Tieslau C, Lankester A. Reactions of normal and tumour cell surfaces to enzymes. I. Wheat germ lipase and associated mucopolysaccharides. Proc Natl Acad Sci USA 1963;50:613-19.

18 Aub JC, Sanford BH, Cote MN. Studies on reactivity of tumours and normal cells to a Wheat germ agglutinin. Proc Natl Acad Sci USA 1965;54:396-9.

19 Hendrickson MR, Kempson RL. Surgical pathology of the uterine corpus. Philadelphia: WB Saunders, 1980:36-98.

20 West KP, Platts HA, Fletcher A, Walker F. Tissue carbohydrate identification by means of lectins. J Clin Pathol 1982;35:239-40.

21 Bancroft JD, Cook HC. Manual of histological techniques. London: Churchill Livingstone, 1984:116-17.

22 Allen AK, Neuberger A, Sharon N. The purification, composition and specificity of Wheat germ agglutinin. Biochem $J$ 1973;131:155-62.

23 Goldstein IJ, Hammarstrom S, Sundblad G. Precipitation and carbohydrate binding specificity studies on Wheat germ agglutinin. Biochim Biophys Acta 1975;405:53-61.

24 Bhavandan VP, Katlic AW. The interactions of wheat germ agglutinin with sialoglycoproteins-the role of sialic acid. J Biol Chem 1979;254:4000-8.

25 Lotan R, Skutelsky E, Danon D, Sharon N. The purification, composition and specificity of the anti-T lectin from peanut. $J$ Biol Chem 1975;250:8518-23.

26 Springer GF, Desai PR. Human blood group MN and precursor specificities: structural and biomedical aspects. Carbohydr Res 1975;40:183-92.

27 Etzler ME, Kabat EA. Purification and characterization of a lectin (plant haemagglutinin) with blood group A specificity from Dolichos biflorus. Biochemistry 1970;9:869-77.

28 Jones JM, Feldman JD. Binding of Maclura pomifera lectin to rat lymphoid cells and erythrocytes. J Immunol 1973;111:1765-70.

29 Bausch JN, Poretz RD. Purification and properties of a haemagglutinin from Maclura pomifera seeds. Biochemistry 1977;16:5790-94.

30 Sarkar M, Wu AM, Kabat EA. Immunochemical studies on the carbohydrate specificity of Maclura pomifera lectin. Arch Biochem Biophys 1981;209:204-18.

31 Murphy LA, Goldstein IJ. Five-D-galacto-pyranosyl binding 
isolectins from Bandeiraea simplicifolia seeds. $J$ Biol Chem 1977;252:4739-42.

32 Horejsi V, Kocourek J. Studies on phytohaemagglutinins. XVII. Some properties of the anti-H specific phytohaemagglutinin of the furze seeds (Ulex europaeus). Biochim Biophys Acta 1974;336:329-37.

33 Pereira MEA, Kisailus EC, Gruezo F, Kabat EA. Immunochemical studies on the combining sites of the blood group $\mathrm{H}$ specific lectin -1 from Ulex europaeus seeds. Arch Biochem Biophys 1978;185:108-15.

34 Debray H, Decout D, Strecker G, Spik G, Montreuil J. Specificity of twelve lectins towards oligosaccarides and glycoproteins related to N-glycosyl proteins. Eur J Biochem 1981;117:41-55.

35 Rittman BR, Mackenzie IC. Effects of histological processing on lectin binding patterns in oral mucosa and skin. Histochem $J$ 1983;15:467-74.

36 Hester LL, Kellett WW, Spicer SS, Williamson HO, Pratt-Thomas HR. Effects of sequential oral contraceptive on endometrial enzyme and carbohydrate histochemistry. Am J Obstet Gynecol 1968;102:771-83.
37 McCarty KS (Jnr), Lubahn DB, McCarty KS. Oestrogen and progesterone receptors: physiological and pathological considerations. Clin Endocrinol Metab 1983;12:133-54.

38 Pollow K, Lubbert H, Boquoi E, Kreuzer G, Pollow B. Characterisation and composition of receptors for $17-\beta$-oestradiol and progesterone in human proliferative endometrium and endometrial carcinoma. Endocrinology 1975;96:319-28.

39 Young PCM, Ehrlich CE, Cleary RF. Progesterone binding in human endometrial carcinoma. Am J Obstet Gynecol 1976;125:353-60.

40 Kiein PJ, Vierbuchen M, Fischer J, Shulz K-D, Farrar G, Uhlenbruck $G$. The significance of lectin receptors for the evaluation of hormone dependence in breast cancer. J Steroid Biochem 1983;19:839-44.

Requests for reprints to: Dr K P West, Department of Pathology, Clinical Sciences Building, Leicester Royal Infirmary, PO Box 65, Leicester LE6 7LX, England. 